\title{
Phytoplankton biodiversity and NW Mediterranean Sea warming: changes in the dinoflagellate genus Ceratium in the 20th century
}

\author{
Alina Tunin-Ley ${ }^{1,2}$, Frédéric Ibañez ${ }^{1,2}$, Jean-Philippe Labat ${ }^{1,2}$, Adriana Zingone ${ }^{3}$, \\ Rodolphe Lemée ${ }^{1,2, *}$
}

${ }^{1}$ Université Pierre et Marie Curie-Paris 6, Laboratoire d'Océanographie de Villefranche, 06230 Villefranche-sur-Mer, France ${ }^{2}$ CNRS, Marine Microbial Ecology Group, Laboratoire d'Océanographie de Villefranche, 06230 Villefranche-sur-Mer, France ${ }^{3}$ Stazione Zoologica Anton Dohrn, Villa Comunale, 80121 Napoli, Italy

\begin{abstract}
Our knowledge of the response of phytoplankton to climate change is restricted by the lack of phytoplankton long-term studies, especially those reporting species data. To circumvent this problem, we combined recent data from sampling at monitoring sites with old bibliographic data. The study was conducted on the genus Ceratium (planktonic dinoflagellates) in the NW Mediterranean, as numerous studies have been conducted in the area since the beginning of the 20th century. In addition, species of this highly diverse genus are known to be particularly sensitive to water temperature, and should thus be responsive to global warming. The temporal distribution of Ceratium species over the last century showed a progressive disappearance from the surface layer of likely stenothermic species, which may have moved to deeper layers in response to water warming, along with a decrease of species richness during the annual cycle. Seasonal and phenological aspects of Ceratium assemblages were also affected, as illustrated by the earlier timing in the minimum of richness. A change in the overall species assemblage also occurred from past to present in the Ligurian Sea, suggesting a warming in this area consistent with the development in surface water temperatures. Our results suggest that Ceratium species may constitute good biological indicators of warming in the NW Mediterranean Sea. In addition, the present study showed the importance of time-series data and the value of historical literature as the basis for ecological studies of long-term trends needed to substantiate our current understanding of the impact of global change on marine biodiversity.
\end{abstract}

KEY WORDS: Ceratium - Phytoplankton - Climate change - Long-term series - Mediterranean · Biodiversity $\cdot$ Biological indicator $\cdot$ Historical ecology

Resale or republication not permitted without written consent of the publisher

\section{INTRODUCTION}

Global climate change, as a new forcing process on Earth, has been debated for a long time. It is now largely recognized by scientists as well as by policy makers and the public. While numerous studies addressing this topic increase our understanding of the potential impacts of climate change on the marine environment, forecasting future scenarios remains difficult due to the complexity of the interactions that link atmospheric and oceanic compartments (Murphy et al. 2004). The Mediterranean Sea offers a good model for studies in this field, because it can be considered as a miniature world ocean (Béthoux et al. 1999, Duarte et al. 1999, Krijgsman 2002). This semi-enclosed sea is largely oligotrophic, with warm and relatively salty, nutrient-poor waters (Duarte et al. 1999). An interesting aspect of the Mediterranean Sea is the coexistence of peculiar deep ocean processes, like the dense water formation observed in winter in the western basin (Béthoux \& Gentili 1999), and typical coastal features, such as the marked anthropogenic pressure favouring eutrophication (Duarte et al. 1999). In the Mediterranean Sea, trends in increasing water temperatures and salinity have been observed for several decades (Béthoux et al. 1990, Rohling \& Bryden 1992, Béthoux \& 
Gentili 1996, Johnson 1997, Marbà \& Duarte 1997), although periodic patterns such as the 22 to $25 \mathrm{yr}$ period of solar activity may overlay the monotonic trends and mask them (Duarte et al. 1999). Nutrient concentrations, particularly phosphate and nitrogen, have also increased from the early 1960s, probably due to increasing atmospheric and terrestrial inputs, while concentration in silicate has remained relatively constant (Béthoux et al. 2002).

Using different approaches, a number of studies have provided information on the temporal distribution of Mediterranean Sea phytoplankton (Duarte et al. 1999, Goffart et al. 2002, Marty et al. 2002, Gómez \& Gorsky 2003, Bosc et al. 2004, Ribera d'Alcalà et al. 2004). Some of these studies show changes in phytoplankton in the NW Mediterranean in relation to climatic forcing. Pigment analysis over a decade revealed a positive trend in phytoplankton biomass in response to the lengthening of the summer stratification, accompanied by an increase of small-sized phytoplankton (picoplankton and nanoflagellates) able to support regenerated production and a decline of diatoms, which are responsible for new production (Marty et al. 2002). Other studies based on nutrient, chlorophyll $a$ and pigment measurements also suggest that warming favours picoplankton and flagellates, thus promoting a shift toward a non-siliceous, regenerative system (Béthoux et al. 2002, Goffart et al. 2002). Finally, from remote sensing data, it appears that in recent years the spring bloom has occurred earlier, perhaps in relation with earlier water warming and higher irradiance, whereas the autumn bloom tended to disappear as a possible consequence of a lengthening of the stratification period (Bosc et al. 2004).

Very few studies so far have addressed the impact of environmental and climatic forcing on phytoplankton biodiversity, despite its acknowledged importance in biogeochemical cycles and its role in shaping the trophic web up to the highest levels (Duffy \& Stachowicz 2006). Indeed, such studies are constrained by various problems. For example, it is difficult to know phytoplankton diversity at a given location, even just for selected groups of organisms, because species richness and abundance, and hence the estimated biodiversity, are strongly dependent on sampling method and sampling effort (Tunin-Ley et al. 2007). Another point is the scarcity of phytoplankton long-term series, which are essential for the assessment of temporal variations and their relationship with global change. Considering these challenges, we chose to focus on an armoured dinoflagellate genus, Ceratium Schrank, as a biological model to examine potential effects of global change on phytoplankton biodiversity. This cosmopolitan genus includes about 80 species (Sournia 1986), is found from polar to tropical areas and has been the focus of numerous studies and monographs since the end of the 19th century (e.g. Gourret 1883, Jørgensen 1911, 1920, Trégouboff \& Rose 1957a, b, Halim 1960, Sournia 1967, Dodge 1982, Steidinger \& Tangen 1997), with limited and generally traceable taxonomic changes over time. An advantage offered by this genus is that identification to species level is more feasible than for other phytoplanktonic groups, where it can be limited by the small size of the organisms or may require the use of electron microscopy and molecular tools. Moreover, Ceratium species are known to be sensitive to temperature in terms of biogeography (Dodge \& Marshall 1994), seasonality and morphology (Sournia 1967), and have hence been proposed as biological indicators of water masses (Dodge 1993, Okolodkov 1996, Ochoa \& Gómez 1997, Sanchez et al. 2000, Raine et al. 2002), current regimes (Dowidar 1973) and climate change (Dodge \& Marshall 1994, Johns et al. 2003). In the northwestern Mediterranean Sea, the genus is species-rich and often dominates the armoured dinoflagellates in terms of abundance (Tunin-Ley et al. 2007). In historical terms, Ceratium in the Mediterranean is described by an abundant literature due to the early establishment of several marine stations in the area that greatly favoured plankton studies. These old studies provide timely descriptions of Ceratium species and, although sampling and methods were sometimes less precise than in current studies, they represent an interesting source of information when using an appropriate method of analysis.

Here, historical observations on Ceratium species were added to more recent data in order to build a dataset representing the 20th century from beginning to end, thus circumventing the scarcity of phytoplankton-focused long-term series. Using the genus Ceratium as a biological model, we asked if there was a change in Ceratium species composition over the last century in the NW Mediterranean Sea and, secondarily, if there was a link between changes in Ceratium species composition and temperature over time.

\section{MATERIALS AND METHODS}

Acquisition of historical Ceratium data. The choice of studies that contained Ceratium data was constrained by 3 factors: sampling method, sampling duration, and sampling location. The datasets based on bottle sampling were eliminated, since the study of Ceratium species richness requires the analysis of large volumes of water that is only possible by net sampling. To allow consideration of the species phenology, we retained only the studies related to observations over annual cycles. As we already had data related to Ceratium phenology from 
Villefranche Bay in France (Tunin-Ley et al. 2007), we focused the present study on data from 2 sites in the Ligurian Sea, in Monaco (Monaco) and Genoa (Italy). Data from the West Ligurian Sea were not considered because the Rhone river inputs, which are conveyed westward by the Ligurian-Provencal current (Gómez \& Gorsky 2003), make this area a more nutrient-rich environment compared to the eastern Ligurian and Tyrrhenian Seas, which range from oligotrophic to mesotrophic throughout the annual cycle (Bianchi et al. 1999). The oldest studies from the Ligurian Sea reported the monthly presence of Ceratium species, among other microphytoplankton species, from January 1907 to February 1914 during the Eider cruises conducted in the vicinity of Monaco (Pavillard 1934, 1936, 1937a, 1937b). Three vertical hauls ( 210 to $140 \mathrm{~m}, 140$ to $70 \mathrm{~m}, 70$ to $0 \mathrm{~m}$ ) with a Nansen net (mesh size was not mentioned) were performed monthly at Stns I, II, and III, located at $2485 \mathrm{~m}$, $6300 \mathrm{~m}$ and $13500 \mathrm{~m}$ distance from the Museum of Oceanography of Monaco on a southeast oriented transect. On the same dates, a horizontal surface tow lasting 35 min was carried out using a narrow net (mesh size was not mentioned) and surface water temperature was measured. Data from 1907 were discarded because they were too few. To allow for comparison with other sites, for which the maximal depth never reached $80 \mathrm{~m}$, only the 0 to $70 \mathrm{~m}$ data were retained. As Stns I and II were quite close to each other, the vertical sampling data were pooled. In another study on the annual phytoplankton and Ceratium cycle in Genoa Bay in 1915, sampling and temperature measurements were performed monthly $3 \mathrm{~km}$ offshore Quarto dei Mille, Italy (Forti 1922). The sampling depth was not specified.

In the Tyrrhenian Sea, a lot of phytoplankton-focused studies were conducted mainly in the Naples area. Temporal distribution of surface phytoplankton was studied between April 1929 and March 1931 in Naples Bay, $2 \mathrm{~km}$ offshore the city (Issel 1934) by analysing 15 min horizontal hauls carried out monthly with a medium Apstein net at 3 to $4 \mathrm{~m}$ depth. Unfortunately, water temperature data were not collected in this study. Finally, we used surface data gathered during 4 cruises from February 1969 to February 1970 in the Low Tyrrhenian basin (Stns 5 to 17 in Magazzù \& Andreoli 1971).

Acquisition of current Ceratium data. Samples were collected over 3 annual cycles in the Villefranche Bay (Ligurian Sea) at the 'Point B' long-term monitoring site $\left(43^{\circ} 41.10^{\prime} \mathrm{N}, 7^{\circ} 19.00^{\prime} \mathrm{E}\right)$, which is located at the mouth of the bay (86 $\mathrm{m}$ in depth). From December 2001 to December 2003, a monthly 0 to $80 \mathrm{~m}$ sampling in double oblique angle was performed with a homemade conical phytoplankton net (53 $\mu \mathrm{m}$ mesh size, $54 \mathrm{~cm}$ diameter, $280 \mathrm{~cm}$ length). In 2005, a 0 to $80 \mathrm{~m}$ bimonthly vertical sampling was performed with the same net. The filtered volume was obtained in 2001 to 2003 with a TSK mechanical flowmeter (TsurumiSeiki) and in 2005 from a simple calculation (filtered volume $=$ diameter of plankton net $\times$ depth). Species were identified to the infraspecific level using a light microscope (Alphaphot 2-YS2, Nikon Instruments) and the nomenclature proposed by Sournia (1967) was applied. The counting effort per sample was completed when a plateau in species richness was obtained. Surface water temperature was measured with a CTD during each sampling.

The long-term study site MareChiara (MC) has been monitored bimonthly to weekly since 1984 (Ribera d'Alcalà et al. 2004) in the Gulf of Naples, Tyrrhenian Sea, 2 miles from the coastline over a depth of 0 to $80 \mathrm{~m}$ $\left(40^{\circ} 48.5^{\prime} \mathrm{N}, 14^{\circ} 15^{\prime} \mathrm{E}\right)$. Net sampling has been regularly carried out using a phytoplankton net $(20 \mathrm{~cm}$ diameter, 20 or $40 \mu \mathrm{m}$ mesh-size), towed slowly for 10 to $15 \mathrm{~min}$ in surface waters. We analyzed 4 annual cycles, using the same counting protocols as those specified above, but identifying Ceratium species to the species level. Monthly horizontal surface samples were analysed from the years 1984, 1988 and 2002. In 2005, bimonthly surface samples were counted for the entire year, and 0 to $40 \mathrm{~m}$ vertical tows from June to December. Surface water temperatures were recorded for each observation with a reversed thermometer in 1984 and 1988 and with a CTD in 2002 and 2005. The geographical location of the different sampling sites is shown in Fig. 1.

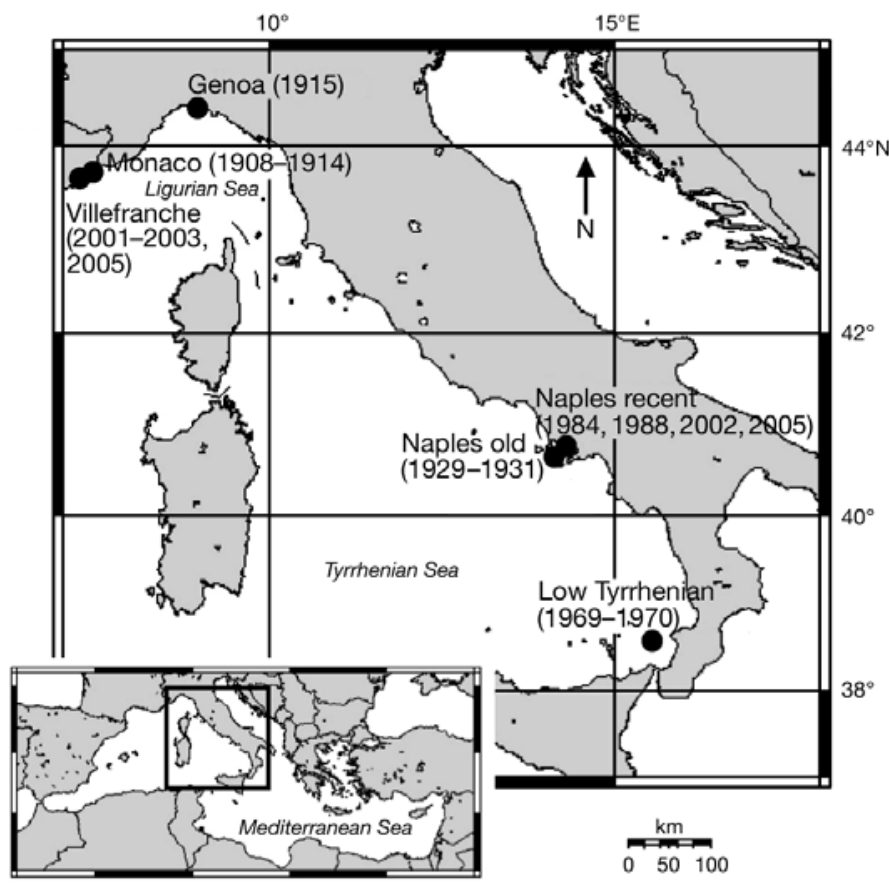

Fig. 1. Location in the northwestern Mediterranean Sea and sampling years for the 6 sites of the studies mentioned 
Construction of the dataset. The different nature of the studies we included, often just reporting the occurrence of Ceratium species in the case of older studies, required the transformation of data from all sites into a homogeneous presence/absence dataset. Information on infraspecific taxa was omitted since only a few studies provided these details. Additionally, we updated the names of the species and harmonised them using a single reference nomenclature following Sournia (1967), as this is the most detailed and clear description of Ceratium species so far available. The characteristics of the final dataset are summarised in Table 1.

Data analysis. Only the 20 species common to all sites were used for statistical analysis. Data from surface horizontal sampling were analysed separately from those from vertical sampling. In order to highlight the main patterns of long-term distribution of Ceratium species, a multiple correspondence analysis (MCA) was applied. The analysis describes the total inertia of a multidimensional set of data in a sample of fewer dimensions (or axes) that is the best summary of the information contained in the data. The method is based on the same principle as the correspondence analysis (CA) (Benzecri 1973), but it is applied to disjunctive tables and uses a chi-squared metric (Legendre \& Legendre 2000), therefore being particularly suitable for binary datasets. Each species is represented by 2 columns, coding for its presence and absence, respectively. The position of a sample in the multivariate space is defined using all 20 Ceratium species. Proximity among samples reflects similar species occurrence in those samples. Illustrative variables that do not contribute to the construction of the factorial space can then be projected on the reduced space in order to determine an ecological explanation for the axes. For example, it is possible to code supplementary illustrative variables like months, years or sampling sites. These composite variables correspond to the mean position in the multivariate space of all samples that validate the variable modality.

To assess the potential effect of seawater temperature on species distribution, we plotted seasonally detrended temperature data in the factorial space of the stations. To this end, a second MCA was performed removing data from the Naples 1929 to 1931 and the Low Tyrrhenian 1969 to 1970 studies, for which temperature data were not available. The sea surface temperature (SST) values were interpolated with the spline cubic method, using the coordinates of the stations of the second MCA analysis that corresponded to the same dates, thus obtaining a scaled area of SST within the space of the MCA (data not shown). Temperature residuals were then obtained for each data point by subtracting the monthly temperature average for that site from the SST value corresponding to that data point. The residuals thus obtained were interpolated as above and represented in the space of the MCA.

\section{RESULTS}

The entire dataset from all studies included information on a total of 46 Ceratium species (Table 2), 20 of which were common to all sites. Four species were found at only one site, of which 3 (Ceratium longipes, C. porrectum and C. schröteri) were limited to Villefranche waters and one (C. lineatum) to the recent dataset from Naples. The total number of Ceratium species per site ranged from 27 to 44 (Table 2). The maximum richness was measured in the recent Villefranche Bay samples, while the lowest was observed in the Low Tyrrhenian Sea in 1969 to 1970. The total number of species was overall higher at Ligurian sites,

Table 1. Data type and sources

\begin{tabular}{|c|c|c|c|c|c|c|c|c|}
\hline Site & $\begin{array}{c}\text { Marine } \\
\text { area }\end{array}$ & $\begin{array}{l}\text { Sampling } \\
\text { period }\end{array}$ & $\begin{array}{l}\text { Sampling } \\
\text { method }\end{array}$ & $\begin{array}{l}\text { Sampled } \\
\text { depth }\end{array}$ & $\begin{array}{c}\text { Water } \\
\text { temper- } \\
\text { atures }\end{array}$ & $\begin{array}{c}\text { No. } \\
\text { obser- } \\
\text { vations }\end{array}$ & $\begin{array}{c}\text { No. } \\
\text { annual } \\
\text { cycles }\end{array}$ & Source \\
\hline Monaco & Ligurian & 1908-1914 & $\begin{array}{c}\text { Horizontal \& } \\
\text { vertical }\end{array}$ & $\begin{array}{c}\text { Surface or } \\
0-70 \mathrm{~m}\end{array}$ & Yes & 211 & $\begin{array}{c}5 \\
(+2 \mathrm{mo})\end{array}$ & $\begin{array}{l}\text { Pavillard (1934, } \\
1936,1937 a, b)\end{array}$ \\
\hline Genoa & Ligurian & 1915 & Horizontal & No information & Yes & 12 & 1 & Forti (1922) \\
\hline Naples old & Tyrrhenian & 1929-1931 & Horizontal & $3-4 \mathrm{~m}$ & No & 24 & 2 & Issel (1934) \\
\hline $\begin{array}{l}\text { Low } \\
\text { Tyrrhenian }\end{array}$ & Tyrrhenian & 1969-1970 & Horizontal & Surface & No & 11 & 1 & $\begin{array}{l}\text { Magazzù \& } \\
\text { Andreoli (1971) }\end{array}$ \\
\hline $\begin{array}{l}\text { Naples } \\
\text { recent }\end{array}$ & Tyrrhenian & $\begin{array}{l}1984,1988 \\
2002,2005\end{array}$ & $\begin{array}{c}\text { Horizontal \& } \\
\text { vertical }\end{array}$ & $\begin{array}{l}\text { Surface or } \\
0-40 \mathrm{~m}\end{array}$ & Yes & 70 & $\begin{array}{c}4 \\
(+7 \mathrm{mo})\end{array}$ & Present study \\
\hline Villefranche & Ligurian & $\begin{array}{c}2001-2003 \\
2005\end{array}$ & Vertical & $0-80 \mathrm{~m}$ & Yes & 50 & $\begin{array}{c}3 \\
(+1 \mathrm{mo})\end{array}$ & Present study \\
\hline
\end{tabular}




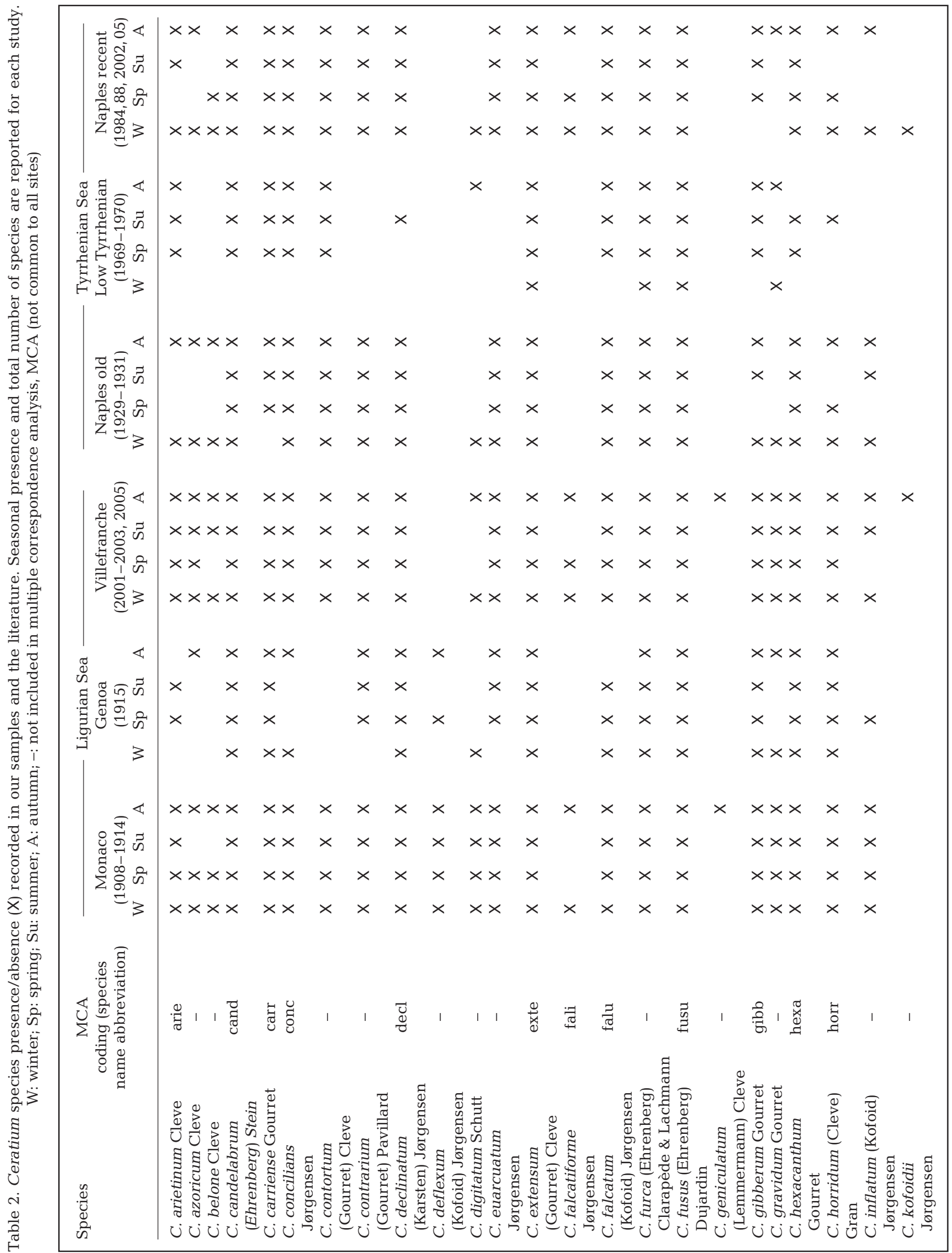




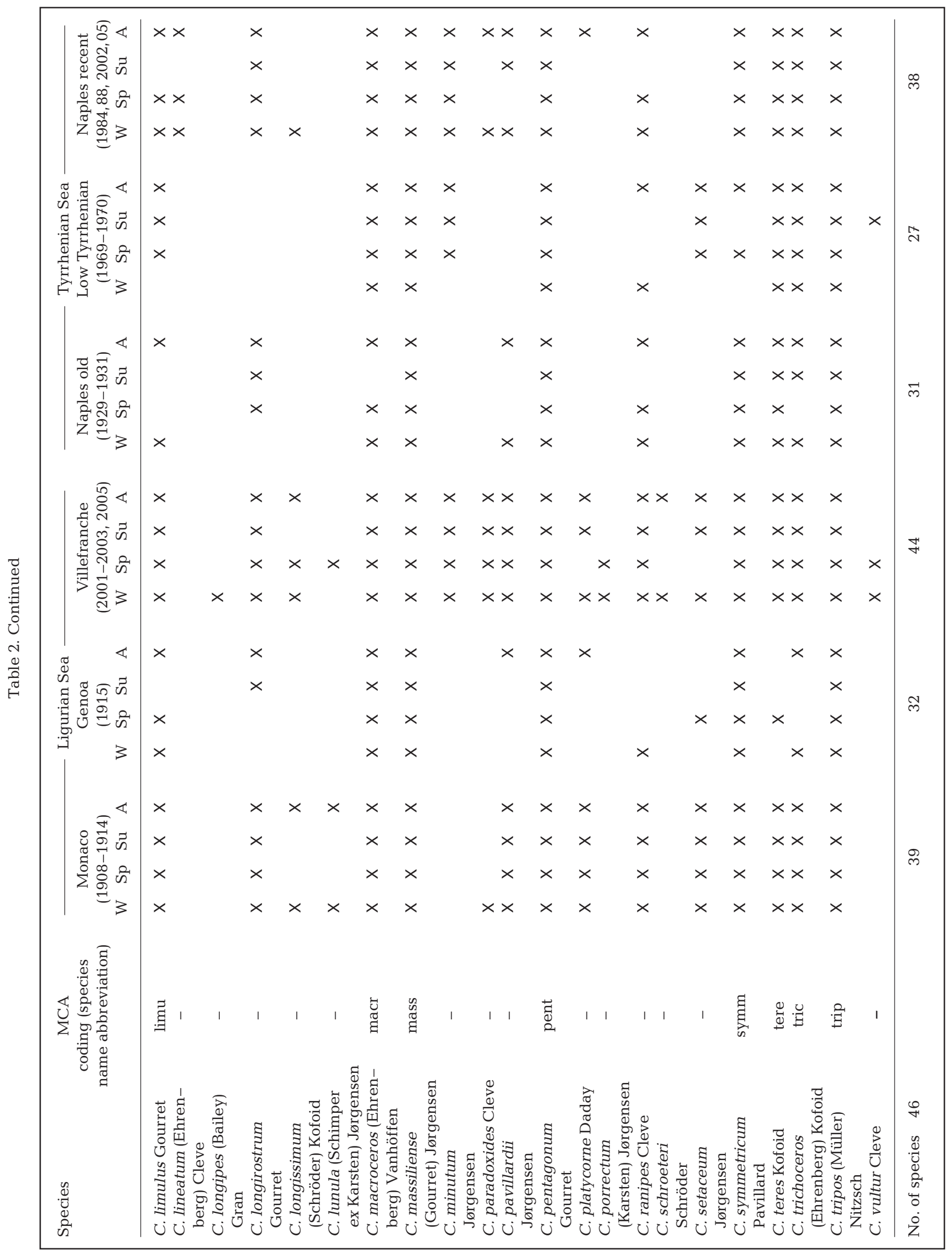


but no clear geographical or temporal trend could be distinguished. The monthly averaged species richness showed different annual patterns among sites (Fig. 2), with periods of maxima and minima, except for the Genoa study and the recent vertical samples from Naples. For most studies, the maximum richness corresponded to the winter period and ranged from 20 to 30 species. The only dataset with both horizontal and vertical hauls, i.e. Monaco, showed higher species richness in the former than in the latter. Species richness, particularly its minimum value, generally decreased in horizontal surface sample data from the literature compared to the present. In contrast, the overall richness in vertical samples was higher in recent data from the Ligurian Sea, although this observation is only based on 2 studies (Monaco and Villefranche). The minimum richness was similar between the 2 studies, but it was found in spring instead of summer in the recent Villefranche dataset.

The MCA also highlighted spatial and temporal variability in the monthly species composition of the genus Ceratium (Fig. 3). Different ecological meanings could be attributed to the first 2 most explanatory axes, which carried 23.6 and $10.2 \%$ of the total inertia, respectively. Axis 1 was characterized by the absence of the 20 common species on its positive part and the presence of the same species on its negative part. This opposition is induced by the method, which builds a disjunctive table resulting in 2 modalities per species:

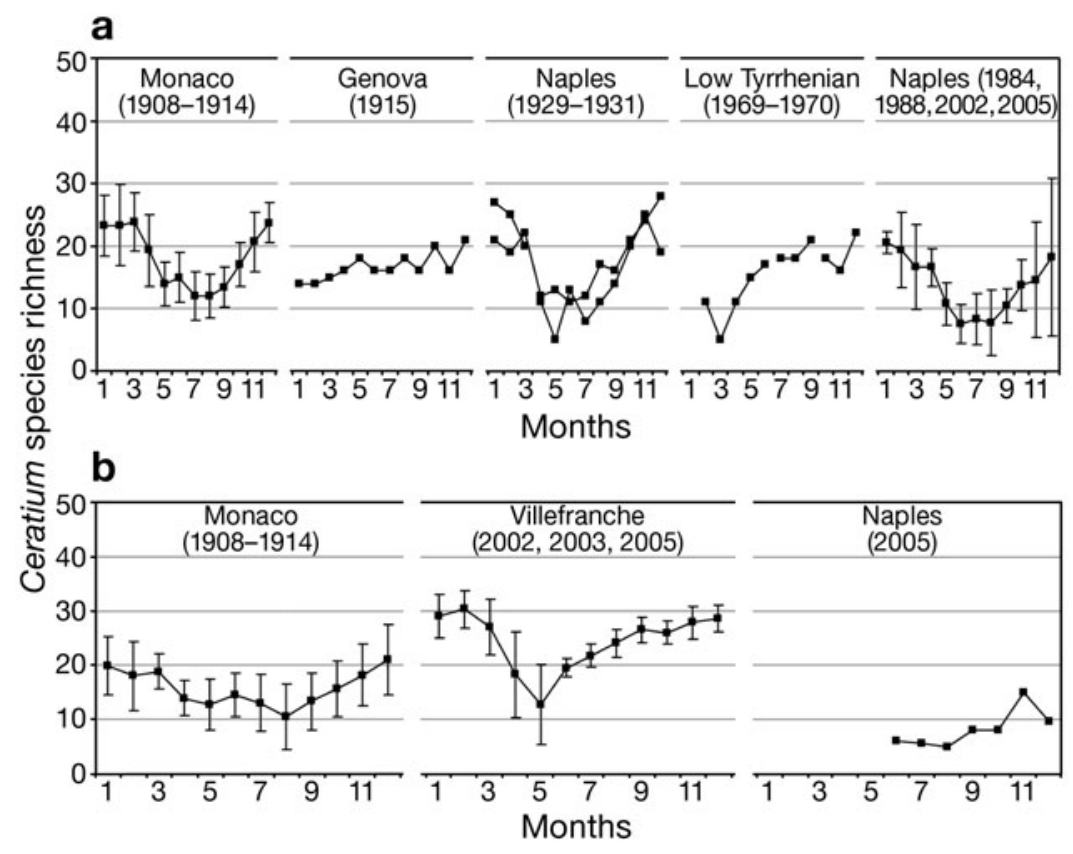

Fig. 2. Monthly average species richness per site throughout the annual cycle. (a) Horizontal surface sampling, (b) vertical sampling. When 2 annual cycles were available, both were plotted; when 3 or more annual cycles were available, error bars representing monthly SD were plotted absence and presence. A marked opposition on Axis 2 between the Ligurian Sea (on the negative part) and the Tyrrhenian Sea (on the positive part) highlighted a difference in the annual composition in Ceratium species between sampling locations. The datasets from Monaco and Genoa obviously had negative coordinates on Axis 2, whereas those from Naples and the Low Tyrrhenian basin were close to the Tyrrhenian Sea dot. Interestingly, the Villefranche study exhibited an intermediate position between the Ligurian and the Tyrrhenian dots, with a positive coordinate on Axis 2, suggesting that the species composition in Villefranche was more similar to that characteristic of Tyrrhenian waters. The last important result of this analysis was the repetitive seasonal cycle demonstrated for Ceratium species composition, independent of location. This was shown by the opposition on the 2 axes between warm (May to September) and cold (November to March) months, with April and October apparently constituting transition periods. The coordinates of the species presence on Axis 2 defined species groups according to location (Fig. 4); species exhibiting the highest positive coordinates $(C$. trichoceros, $C$. teres, C. falcatum and C. extensum) could be considered as more characteristic of the Tyrrhenian Sea and species with extreme negative coordinates (C. Carriense, C. gibberum, C. hexacanthum and C. symmetricum) as associated with Ligurian waters. Species presenting coordinates close to zero (C. tripos, $C$. furca, $C$. concilians and C. declinatum) were observed equally at the different sites.

Temperature residuals were represented in the plane of the MCA performed on datasets for which SST were available (Fig. 5), where the 2 first axes explained most of the total inertia $(22.3$ and $11.9 \%$ surface water observations, 27.6 and $9.21 \%$ MCA on vertical hauls). The surface water observations from the oldest study in Monaco (Fig. 5a) were mostly located on the negative part of Axis 2 and were opposed to the recent observations from Naples, which had positive coordinates on this axis. The old observations from the study in Genoa had intermediate coordinates. A similar opposition on Axis 2 between old observations in Monaco and recent ones in Villefranche and in Naples was apparent in the vertical sampling data (Fig. 5b). These oppositions, which reflected a difference in the annual Ceratium species composition, were related to seasonally detrended water temperatures but not to water temperature (data not shown). 


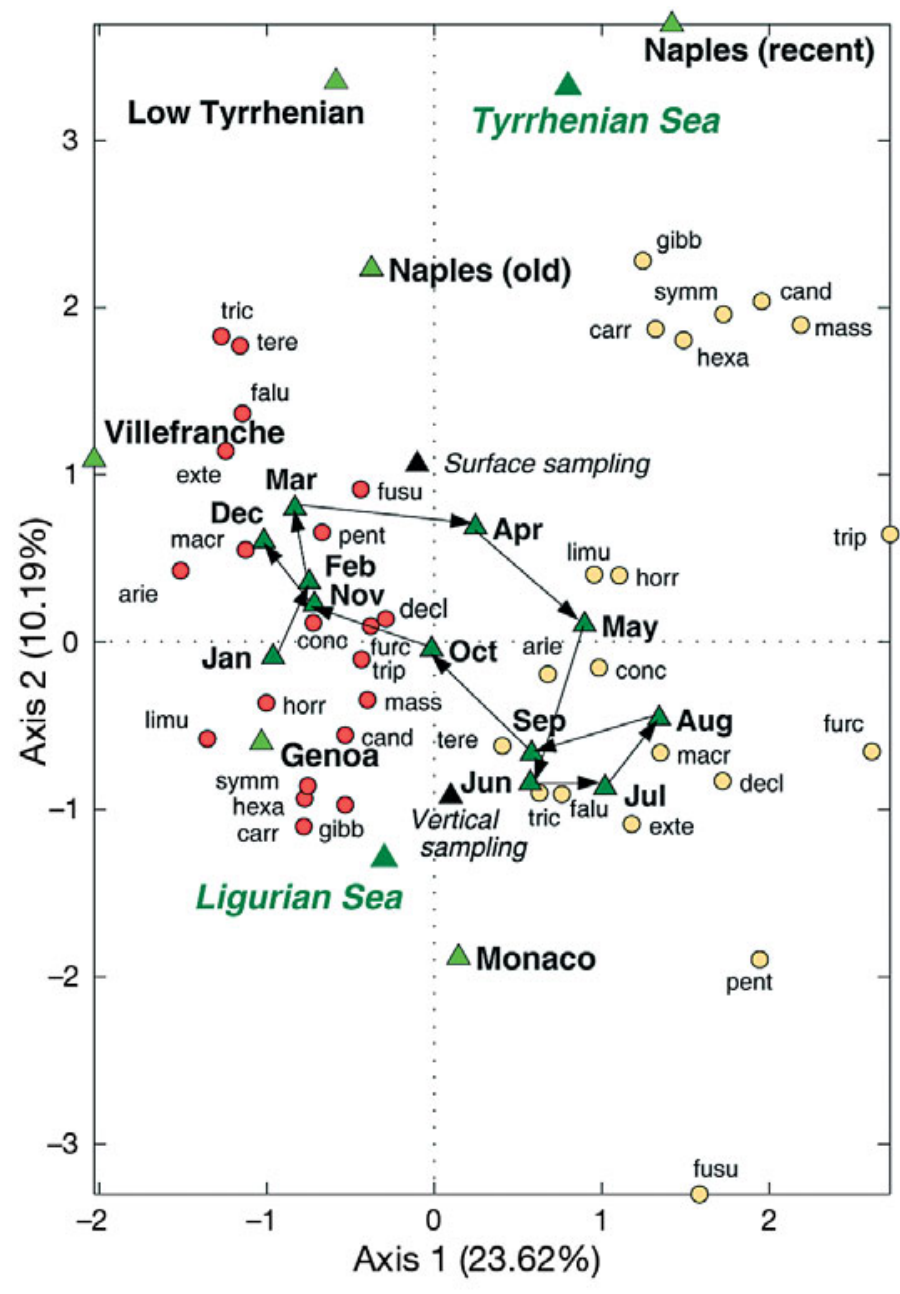

Fig. 3. Results of the MCA applied to the complete dataset. $(\bigcirc)$ : species presence, (O): species absence. Monthly means, study sites and marine areas have been added as illustrative variables (green triangles)

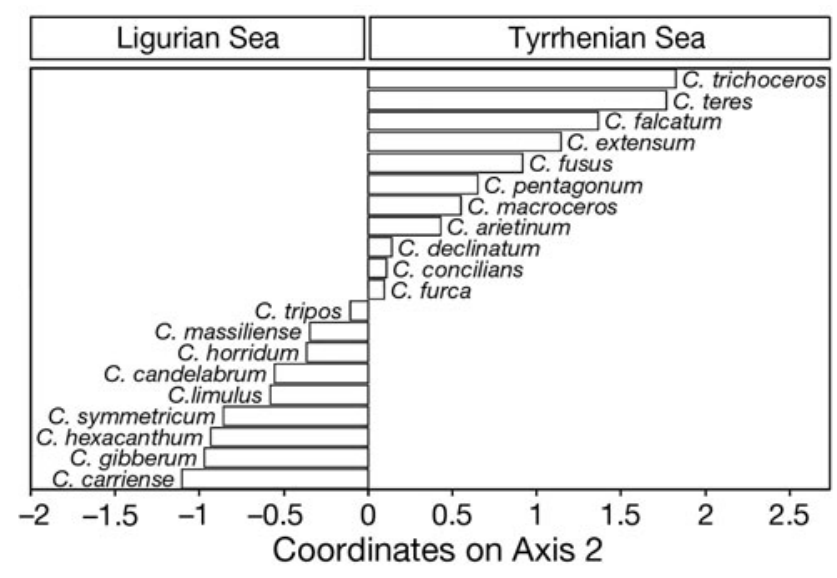

Fig. 4. Coordinates on Axis 2 (from the global dataset MCA) of Ceratium species presence
Indeed, the old observations from the Monaco study corresponded with relatively colder water temperatures for vertical as well as for surface horizontal sampling. In contrast, the recent observations from Villefranche and Naples were associated with relatively warmer temperatures (positive residuals), regardless of the sampling method. C. carriense, C. candelabrum and $C$. hexacanthum presented extreme negative coordinates on Axis 2 for horizontal surface sampling and extreme positive coordinates on Axis 2 for vertical sampling (Fig. 6), hence appearing more closely related to old samples and cold waters. C. arietinum, $C$. falcatum, C. teres and $C$. trichoceros had extreme positive coordinates on Axis 2 for horizontal surface sampling and extreme negative coordinates on Axis 2 for vertical sampling (Fig. 6) and were thus associated with recent samples and warmer waters.

The annual occurrence of Ceratium species at the different sites and relationships with the monthly averaged SST (Fig. 7) showed differences in phenology among species and sites, as well as with temporal changes in temperature. The averaged annual cycle of SST showed a longer warm season in the recent studies compared to the old ones. Warming of the surface waters in Monaco at the beginning of the 20th century began in May, whereas it started in mid-April in the more recent studies. The end of the warm period showed an even stronger delay over time. In the recent studies, SST exceeded $16^{\circ} \mathrm{C}$ in December, whereas it was below $16^{\circ} \mathrm{C}$ in the oldest studies. The peak of heat (above $22^{\circ} \mathrm{C}$ ) also lasted longer (old studies: $2 \mathrm{mo}$; recent studies: $3.5 \mathrm{mo}$ ), was stronger (maximum from about $24^{\circ} \mathrm{C}$ to $25-26^{\circ} \mathrm{C}$ ) and occurred earlier (July to August instead of August to September). As for the phenology, some species had a similar annual occurrence at all sites, which did not really change over the time. Among these, 2 species (C. furca and C. tripos) were perennial and some others (C. fusus, C. massiliense and $C$. pentagonum) were almost perennial, since they were absent only for a couple of months. Most species exhibited neither perennial nor seasonal occurrence. Species such as C. horridum, C. symmetricum and $C$. teres were completely or partially absent from surface waters during the warm period, but were often encountered in deeper waters, although vertical samples generally included less species. The seasonal pattern of some species varied among the sites. In Monaco, C. arietinum, C. horridum, C. macroceros, C. pentagonum, C. symmetricum, C. teres and C. trichoceros were less frequently present or completely absent from surface waters during the warm season, whereas all except $C$. teres were completely absent from the vertical samples. In Genoa, only C. declinatum and $C$. symmetricum disappeared during the warm season. By contrast, C. arietinum was restricted 

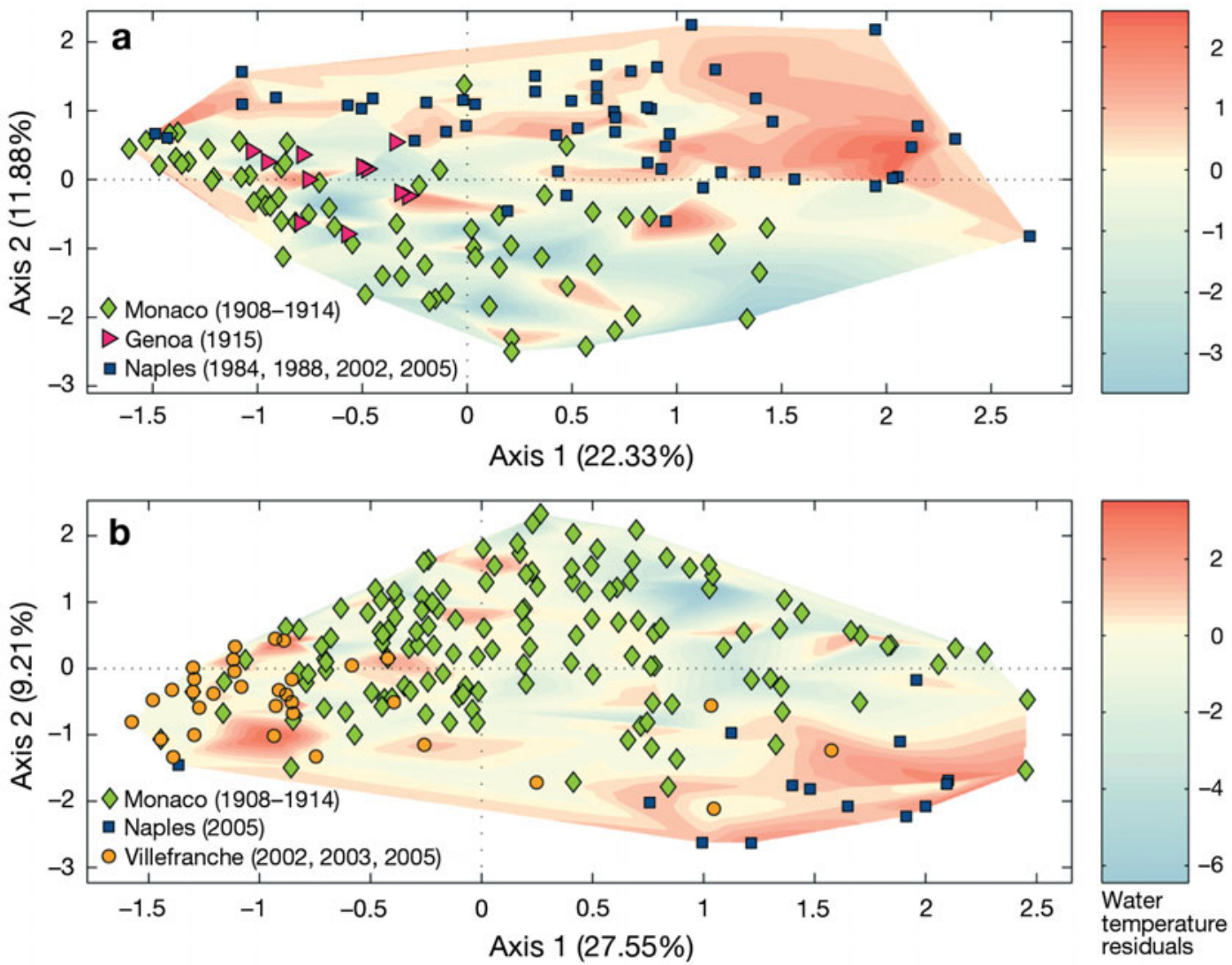

Fig. 5. Relationship between stations and interpolated surface water temperature residuals. Station coordinates result from the second MCA applied to data with available water temperatures. (a) Horizontal surface sampling, (b) vertical sampling

a
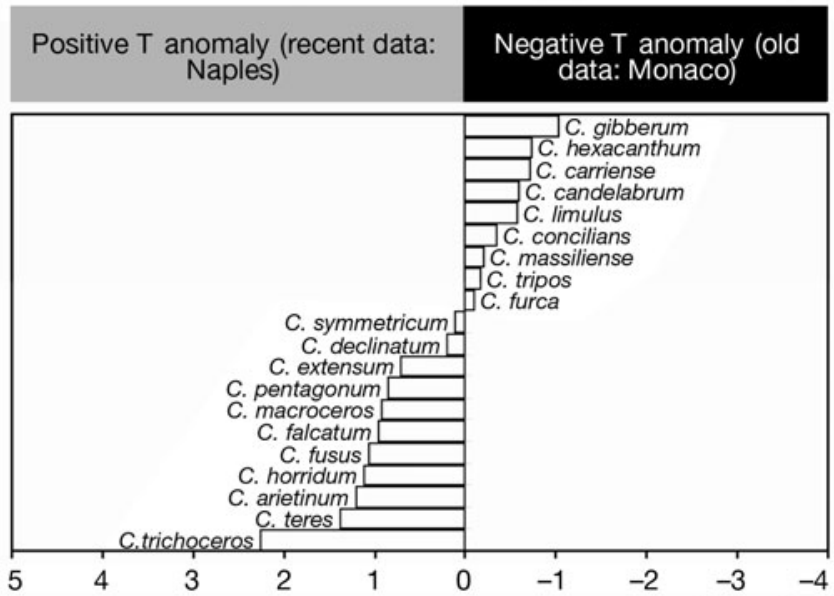

b

Positive T anomaly (recent data: Naples \& Villefranche)

\section{Negative $T$ anomaly (old} data: Monaco)

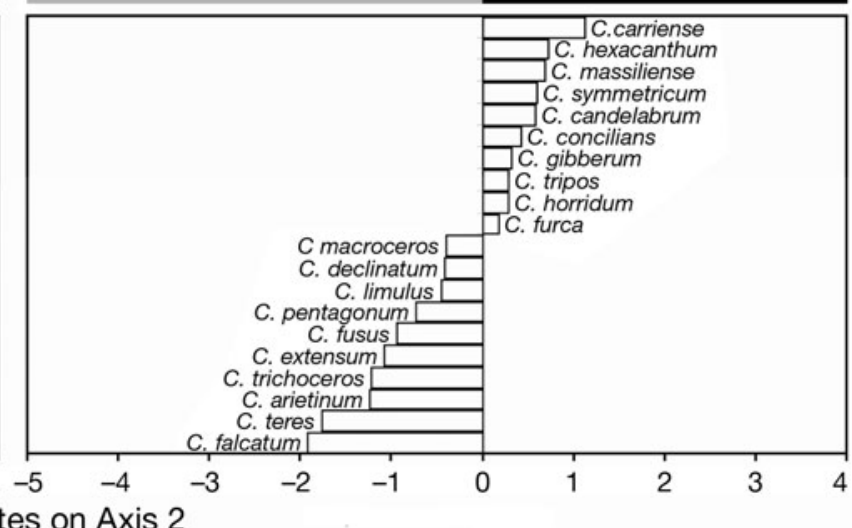

Fig. 6. Coordinates on Axis 2 (from the second MCA) of species presence. (a) Horizontal surface sampling, (b) vertical sampling

to the warm period. In the old study conducted in Naples, many species were not found during summer and/or late spring. The study conducted in the Low Tyrrhenian Sea differed from the others because no species were strictly absent during summer, yet some were absent from mid-winter to spring and others were present during various seasons. In recent surface samples from Naples, C. arietinum, C. horridum, $C$. limulus, $C$. symmetricum and $C$. teres were not encountered during the warm period. In vertical sam- 

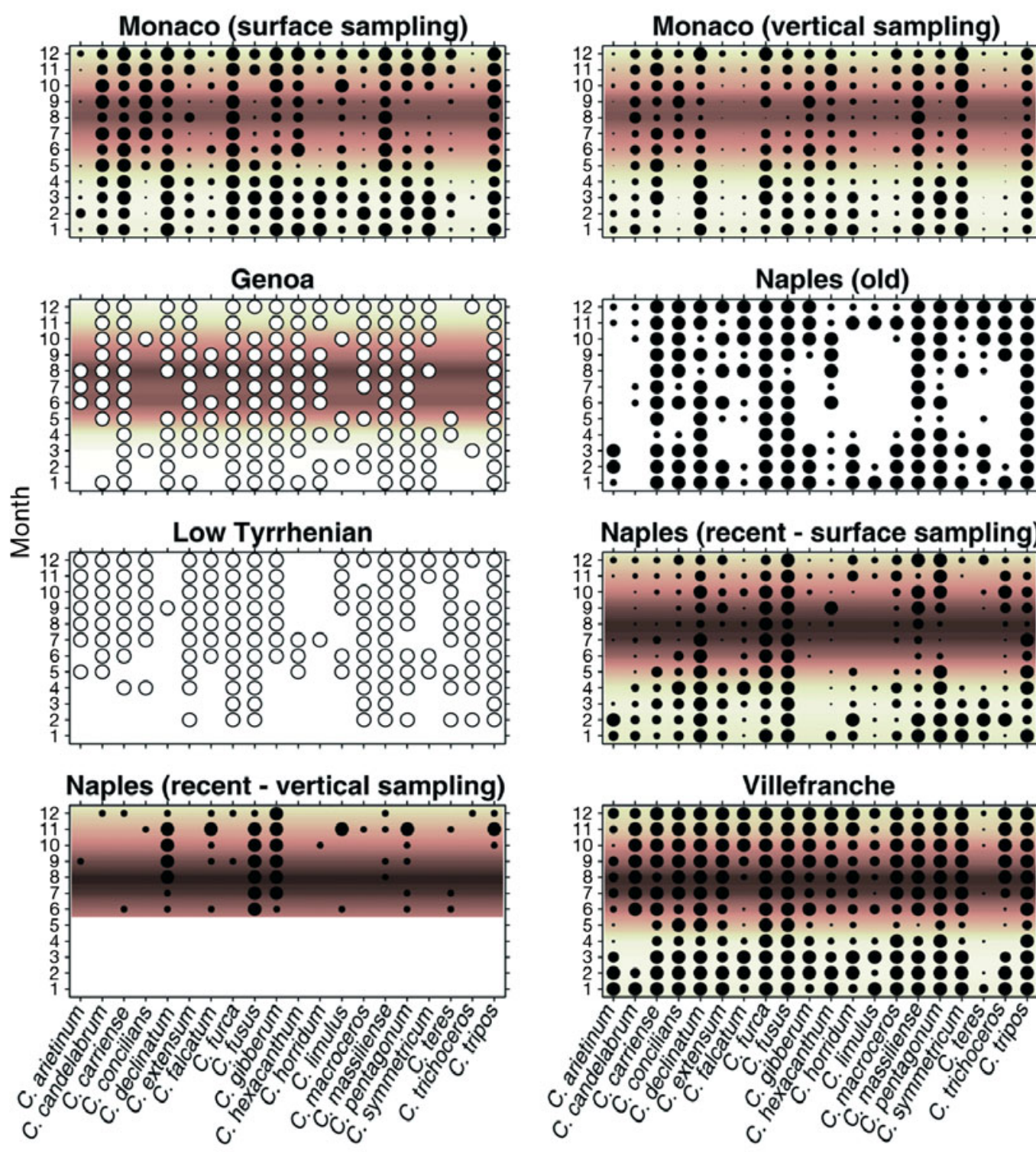

Mean surface water temperature $\left({ }^{\circ} \mathrm{C}\right)$
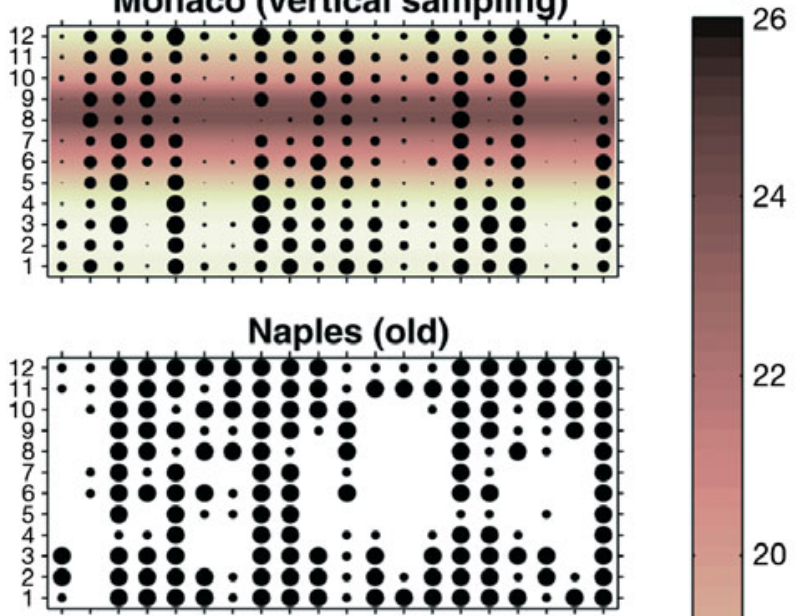

Naples (recent - surface sampling)

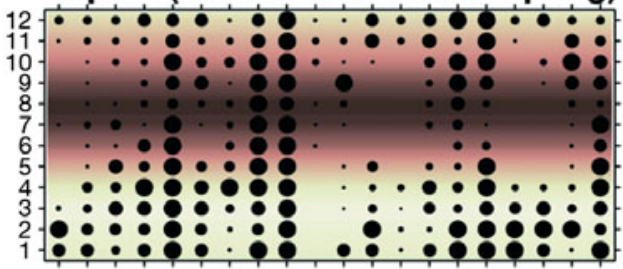

18

20

22

24

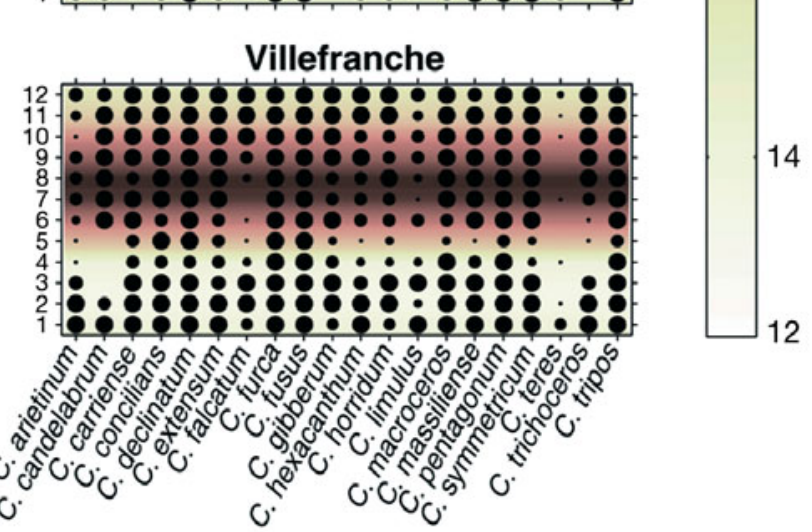

16

14

12

Fig. 7. Relative monthly presence of Ceratium species throughout the annual cycle for each site, (O) dot size is proportional to the relative monthly presence in each month. (O): Only one annual cycle was available. Mean monthly surface water temperatures have been added when available

ples from Naples, the incomplete annual cycle did not allow conclusions regarding any thermal preference of the species. Finally, in vertical samples from Villefranche, none of the species displayed a clear seasonal preference, except $C$. teres, although it was scarcely observed throughout the 3 annual cycles. A change was observed in the phenology of 4 species (C. Carriense, C. gibberum, C. hexacanthum and C. limulus), which were rather perennial in the old studies but became less present in the recent surface samples and were frequently undetected alltogether.

\section{DISCUSSION}

In spite of the constraining aspects of our long-term dataset (data scattered over time, different sampling depths, lack of quantitative data, few hydrological data), we found some trends that may be related to warming. The annual composition of the Ceratium community in terms of species occurrence and species associations has changed with time and may be a response to local warming. Indeed, the species composition in Villefranche seems to have shifted towards that 
found in Tyrrhenian waters, which suggests warmer conditions in the Ligurian Sea, given that the Tyrrhenian waters are generally warmer than in Villefranche. Changes observed in Ceratium species were more subtle than expected. A common response to climatic warming is the appearance, and potentially subsequent increase, of non-indigenous species of warmer affinities, resulting from an expansion of their distribution range. Such phenomena have indeed been described for several terrestrial (Parmesan et al. 1999, van Herk et al. 2002, Parmesan \& Yohe 2003) and marine (Francour et al. 1994, Nehring 1998, Walther 2000) ecosystems. Interestingly, we found that the Ceratium species that recently appeared in Villefranche Bay (C. longipes, $C$. porrectum and C. schröteri) are considered cold-temperate species (Sournia 1967, Dodge \& Marshall 1994, Steidinger and Tangen 1997) and were encountered in winter. They may have naturally arrived via the Strait of Gibraltar or have been introduced by ships' ballast water. Indeed, dinoflagellates, mostly cysts but also vegetative cells, can survive in seawater ballast and are able to colonize new sites in this way (Hallegraeff \& Bolch 1991, 1992, Lavoie et al. 1999). Rather than by water temperatures, which remain quite homogenous during the winter period in the northwestern Mediterranean, these cold-water species were probably favoured by other factors such as nutrient availability. Indeed, in the northwestern Mediterranean, an increase in concentrations of nitrates and phosphates in deeper layers has been observed since the 1960s, corresponding to the intensification of anthropogenic activities (Béthoux et al. 1992). The few species which are characteristic of warm waters, such as C. geniculatum, C. lunula or C. vultur (Sournia 1967), did not display any trend of increasing occurrence and were scarcely observed both in the older study and in recent samples. Interestingly, the main change observed was the disappearance over time of several species during a sensu lato summer period from historical observations to recent ones. From a global outlook, it seemed that Ceratium species were responsive to warming in terms of thermal tolerance rather than thermal preference. Thus, the maximum temperature threshold would affect distribution of Ceratium species in the Mediterranean Sea in the same way as the lower limit of the temperature range dictates the northern boundaries of other species in cold-temperate waters (Dodge \& Marshall 1994). In our case, the lower proportion of species disappearing during the warm period in vertical observations suggested that stenothermal species likely would find more suitable conditions in the colder waters under the thermocline. This assumption was supported by the decrease of annual species richness from past to present in surface observations while it tended to increase in vertical ones.
Determining how an increase in average temperature may affect the annual specific composition in the genus Ceratium obviously is not a simple affair, especially when considering only presence/absence data. Besides the direct impact of temperature on physiology, climate change may affect species distribution indirectly through changes of the hydrographical or trophic conditions, with consequences that in some cases may become manifest after some years due to biological and hydrographical resilience. In the central North Sea C. furca, like other potentially harmful dinoflagellate species, has become more abundant over the last 4 decades and its distribution has moved northward since the 1990s while the area experienced a warm period since the end of the 1980s (Edwards et al. 2006). In Villefranche Bay, C. furca exhibits a peak of abundance during spring that often corresponds to its dominance over other Ceratium species (Halim 1960, Gómez \& Gorsky 2003, Tunin-Ley et al. 2007). A recent study has demonstrated that the dominance of C. furca during spring was associated with an important bloom of salps in the bay, likely responsible for the drastic drop-off in other Ceratium species (Tunin-Ley et al. 2007). The mechanisms that allow C. furca to avoid predation by salps are unknown, but they may be related to specific abilities for mixotrophy that would allow this species to live in deeper waters where light is limiting for other species and salps may be absent (Tunin-Ley et al. 2007). Indeed, mixotrophic behaviour has been observed in several Ceratium species, including $C$. furca (Smalley et al. 1999) and $C$. fusus (Mikaelyan \& Zavyalova 1999).

Based on their vertical and spatial distribution, Sournia (1967) distinguished euphotic from oligophotic and neritic from oceanic Ceratium species. These descriptors potentially reflect different trophic abilities, as mixotrophic organisms are theoretically less dependent on nutrient availability and irradiance. In the present study, mixotrophic abilities could explain observed differences in species composition between the Ligurian and Tyrrhenian Seas and their change with time. By enhancing the summer stratification, warming could favour mixotrophic species that are able to overcome nutrient depletion above the thermocline and low irradiance under the thermocline.

The biogeographical features of the species examined here seemed to have no influence on the typical Ligurian and Tyrrhenian associations; the species that we considered distinctive of the Ligurian (Ceratium trichoceros, C. teres, C. falcatum and C. extensum) and the Tyrrhenian (C. carriense, C. gibberum, C. hexacanthum and C. symmetricum) associations are all considered temperate-tropical, with the exception of $C$. hexacanthum which is described as more cosmopolitan (Sournia 1967, Dodge \& Marshall 1994, Steidinger \& 
Tangen 1997). Due to its geological history and diverse climatic and hydrological conditions, the Mediterranean Sea shelters species exhibiting different affinities, from cold-temperate to tropical conditions (Bianchi \& Morri 2000, Bianchi 2007). Among Ceratium species, all biogeographical origins are represented in the northwest Mediterranean, with an important mix of species that everywhere else are restricted to the intertropical area. Nonetheless, 2 typical Ligurian species (C. carriense and C. hexacanthum) were strictly associated with old observations and negative temperature residuals, while the typical Tyrrhenian species $C$. trichoceros and $C$. teres were characteristic of recent samples from Villefranche and Naples and positive temperature residuals. This strongly suggested that temperature affected these particular species and, to a lesser extent, the other species. The stenothermal character may explain the observed differences in species associations between the Ligurian and Tyrrhenian Seas, yet this aspect remains unexplored in the literature. Furthermore, these typical species are not specifically associated with any depth or environment, which makes it difficult to infer any link with mixotrophic status.

In marine pelagic ecosystems, phenological changes related to global warming have been studied mostly in cold-temperate areas. For example in the North Sea, the seasonal peak appeared to occur earlier for some planktonic groups, but not for all, which could lead to a decoupling of the trophic relationships that connect these groups (Edwards \& Richardson 2004). Different from diatoms, which did not change their timing, dinoflagellates were among the groups responding to warming with an earlier occurrence of the seasonal peak for several genera, especially Ceratium (Edwards \& Richardson 2004). This is consistent with the change in timing that we found in the present study, with the species richness minimum moving from summer to mid-spring. Like the observed variations in species associations, this phenological change might result directly from local warming. However, it could also depend on other factors that varied in relation to temperature, such as reduced nutrient availability, which may favour some Ceratium taxa with mixotrophic characteristics or shifts in seasonal zooplankton peak, which may strongly affect the Ceratium species richness in some cases (Tunin-Ley et al. 2007).

Several types of biological indicators of climatic change have been suggested, for example abundance of individual taxa, functional attributes of the ecosystem, species assemblages and phenological traits (Beaugrand 2005). Various changes in Ceratium species observed in the Ligurian Sea may be used as indicators of warming in the northwest Mediterranean Sea and in other areas. First, the diminished occurrence of certain Ceratium species during the warm season in surface waters is an important sign of change. Among these, C. teres, but also C. symmetricum and C. horridum to a lesser extent, could be proposed as indicators of warming since they seemed to be limited by a maximum temperature threshold. However, the 2 latter species display several infraspecific taxa that may respond differently to the warming, although only the infraspecific taxa in C. horridum seemed to be limited by thermal conditions (Sournia 1967). More generally, Ceratium species composed of several infraspecific forms might not be good candidates as biological indicators, since these forms often correspond to seasonal variants (Sournia 1967), which may allow a species to be perennial. In these cases, an infraspecific taxon known to be thermophilic or psychrophilic may be more relevant. Another good indicator of change is the total Ceratium species richness in summer, assuming that Ceratium species are sensitive to warming in terms of maximum temperature tolerance, as suggested by the present study. The phenological traits of Ceratium species may also be used, as the seasonal character of their annual cycle is strongly marked. Among these, the timing of the minimum of total species richness would be an interesting indicator of warming; as this is often associated with the dominance of C. furca (Tunin-Ley et al. 2007), changes of this species could be also monitored. Variations in the abundance of individual species, which were not considered in the present study, would likely provide relevant information about the impact of warming. Finally, it is expected that species from the tropical Atlantic or from the warmer eastern Mediterranean basin will be able to expand their distribution into the northwest Mediterranean given an increase in average temperature, as has happened in recent years with several benthic invertebrates, macroalgae and fish species (Bianchi 2007). Among species either absent or very scarce in the western basin but common in the eastern basin, C. breve, C. egyptiacum and C. reflexum (Gómez 2003) could be given special attention, as they are potential candidates for a range expansion over the next several decades towards the northwest Mediterranean.

Assessing the response of phytoplankton to climate change represents a huge and far from overcome challenge. Long-term monitoring of phytoplankton is certainly the most robust approach to understand how external forcing drives the variation in phytoplankton biodiversity. As a complement, the method used in the present study offers new opportunities for planktonfocused analysis in the framework of climate change by considering and integrating a significant amount of data from the literature and showing that it is possible to overcome problems caused by disparity among 
datasets. For example, this kind of approach could be applied to the profuse datasets on copepods, for which sampling and especially net mesh size often differ from one study to another. Thus, it becomes possible to extract unexpected information from huge datasets because fundamental differences in methodology can be taken into account in the interpretation.

One of the unexpected effects of warming observed in the present study was the disappearance of species less tolerant to temperature change, rather than the appearance of warmer water species. This trend, wellknown for stenothermic benthic groups like corals, was not thought to be important for plankton, where spreading abilities should favour colonisation rather than local decline. While an increase of biodiversity can result, at least temporarily, from range expansion coupled with limited local extinctions, in this case the disappearance of some species may cause a loss of biodiversity if not balanced with immigration of tropical species. On the other hand, the deepening of the stenothermic species may be considered as colonisation over the vertical dimension, a response to warming already observed for fish species (Perry et al. 2005) that is likely to occur for phytoplankton in future decades.

The present study provides further evidence of the difficulty in assessing long-term changes in phytoplankton species and assemblages due to the scarcity of the data that are globally and locally available. The mere lack of environmental data limited the ecological interpretation of the observed biological changes and their implications in a context of global change. In spite of the numerous samples that we pooled, our work did not allow us to statistically confirm the trends we observed in Ceratium species composition. However, obvious changes were identified that actually correspond to strong signals, considering the limits of the dataset. Thus, if we cannot propose a general pattern for the consequences of climate change on phytoplankton diversity, we demonstrated that Ceratium species composition has subtly changed over the last century in a way that parallels water warming in the Ligurian Sea. In the context of global change, the present study suggested that investigations on its impacts on biodiversity may be largely facilitated by the search for specific biological indicators that allow the restraint of monitoring effort to relevant responsive parameters.

Acknowledgements. We thank the sailors of the Observatoire Océanologique de Villefranche J. Y. Carval and J. L. Prevost for sampling at 'Point B', and the crew of the R/V 'Vettoria' of the Stazione and members of the Office of Management and Ecology of Temperate and Polar Coastal Areas at the Zoologica Anton Dohrn for sampling and temperature data of the MC station in the Gulf of Naples. This work was supported by the MarBEF European Network of Excellence 'Marine Biodiversity and Ecosystem Functioning' in the framework of the program MARPLAN for European integration of marine microplankton research. Financial support was provided by INSU of the CNRS through the project CNRS-INSU ATI \#01N50/0388 'Effet du Mesozooplancton sur la Diversité des Compartiments Phyto- et Microzooplanctonique d'une Zone Côtière Méditerranéenne', by the ANR AQUAPARADOX and the project 'La Notion d'Espèce dans le Phytoplancton' in the framework of the CNRS/INSU national program EC2CO 'Ecosphère Continentale et Côtière'. We thank J. Dolan for English corrections.

\section{LITERATURE CITED}

Beaugrand G (2005) Monitoring pelagic ecosystems using plankton indicators. ICES J Mar Sci 62:333-338

Benzecri JP (1973) L'analyse des données. II. L'analyse des correspondances. Dunod, Paris

Béthoux JP, Gentili B (1996) The Mediterranean Sea, coastal and deep-sea signatures of climatic and environmental changes. J Mar Syst 7:383-394

Béthoux JP, Gentili B (1999) Functioning of the Mediterranean Sea: past and present changes related to freshwater input and climate changes. J Mar Syst 20:33-47

Béthoux JP, Gentili B, Raunet J, Tailliez D (1990) Warming trend in the western Mediterranean deep water. Nature 347:660-662

Béthoux JP, Morin P, Madec C, Gentili B (1992) Phosphorus and nitrogen behaviour in the Mediterranean Sea. DeepSea Res II 39:1641-1654

Béthoux JP, Gentili B, Morin P, Nicolas E, Pierre C, Ruiz-Pino DP (1999) The Mediterranean Sea: a miniature ocean for climatic and environmental studies and a key for the climatic functioning of the North Atlantic. Prog Oceanogr 44: 131-146

Béthoux JP, Morin P, Ruiz-Pino DP (2002) Temporal trends in nutrient ratios: chemical evidence of Mediterranean ecosystem changes driven by human activity. Deep-Sea Res II 49:2007-2016

Bianchi CN (2007) Biodiversity issues for the forthcoming tropical Mediterranean Sea. Hydrobiologia 580:7-21

Bianchi CN, Morri C (2000) Marine biodiversity of the Mediterranean Sea: situation, problems and prospects for future research. Mar Pollut Bull 40:367-376

Bianchi M, Fosset C, Conan P (1999) Nitrification rates in the NW Mediterranean Sea. Aquat Microb Ecol 17:267-278

Bosc E, Bricaud A, Antoine D (2004) Seasonal and interannual variability in algal biomass and primary production in the Mediterranean Sea, as derived from 4 years of SeaWiFS observations. Global Biogeochem Cycles 18:GB1005. doi:10.1029/2003GB002034

Dodge JD (1982) Marine dinoflagellates of the British Isles. Her Majesty's Stationery Office, London

Dodge JD (1993) Biogeography of the planktonic dinoflagellate Ceratium in the Western Pacific. Korean J Phycol 8: 109-119

> Dodge JD, Marshall HG (1994) Biogeographic analysis of the armoured planktonic dinoflagellate Ceratium in the North Atlantic and adjacent seas. J Phycol 30:905-922

Dowidar NM (1973) Distribution and ecology of Ceratium egyptiacum Halim and its validity as an indicator of the current regime in the Suez Canal. J Mar Biol Assoc India 15:335-344

> Duarte CM, Agustí S, Kennedy H, Vaqué D (1999) The Mediterranean climate as a template for Mediterranean marine ecosystems: the example of the northeast Spanish littoral. Prog Oceanogr 44:245-270 
Duffy JE, Stachowicz JJ (2006) Why biodiversity is important to oceanography: potential roles of genetic, species, and trophic diversity in pelagic ecosystem processes. Mar Ecol Prog Ser 311:179-189

Edwards M, Richardson AJ (2004) Impact of climate change on marine pelagic phenology and trophic mismatch. Nature 430:881-884

Edwards M, Johns DG, Leterme SC, Svendsen E, Richardson AJ (2006) Regional climate change and harmful algal bloom in the northeast Atlantic. Limnol Oceanogr 51: $820-829$

Forti A (1922) Ricerche su la flora pelagica (fitoplancton) di Quarto dei Mille (Mare Ligure). R Comit Thalass Mem 97: $1-248$

Francour $\mathrm{P}$, Boudouresque CF, Harmelin JG, HarmelinVivien ML, Quignard JP (1994) Are the Mediterranean waters becoming warmer? Information from biological indicators. Mar Pollut Bull 28:523-526

Goffart A, Hecq JH, Legendre L (2002) Changes in the development of the winter-spring phytoplankton bloom in the Bay of Calvi (NW Mediterranean) over the last two decades: A response to changing climate? Mar Ecol Prog Ser 236:45-60

Gómez F (2003) Checklist of Mediterranean free-living dinoflagellates. Bot Mar 46:215-242

Gómez F, Gorsky G (2003) Microplankton annual cycles in the Bay of Villefranche, Ligurian Sea, NW Mediterranean. J Plankton Res 25:323-339

Gourret P (1883) Sur les péridiniens du golfe de Marseille. Ann Mus Hist Nat Marseille 1:1-114

Halim Y (1960) Etude quantitative et qualitative du cycle écologique des dinoflagellés dans les eaux de Villefranche-sur-Mer. Ann Inst Oceanogr Monaco 38:123-232

Hallegraeff GM, Bolch CJ (1991) Transport of toxic dinoflagellate cysts via ships' ballast water. Mar Pollut Bull 22: $27-30$

> Hallegraeff GM, Bolch CJ (1992) Transport of diatom and dinoflagellate resting spores in ships' ballast water: implications for plankton biogeography and aquaculture. J Plankton Res 14:1067-1084

Issel R (1934) Ciclo annuale del microplancton di superficie del golfo di Napoli (golfo interno). PSZNI Mar Ecol 14: $1-50$

Johns DG, Edwards M, Richardson A, Spicer JI (2003) Increased blooms of a dinoflagellate in the NW Atlantic. Mar Ecol Prog Ser 265:283-287

- Johnson RG (1997) Climate control requires a dam at the strait of Gibraltar. EOS Trans Am Geophys Union 78: $277-281$

> Jørgensen E (1911) Die Ceratien. Eine kurze Monographie der Gattung Ceratium Schrank. Int Rev Ges Hydrobiol 4: $1-124$

Jørgensen E (1920) Mediterranean Ceratia. Rep Dan Oceanogr Exped Mediter II:1-110

Krijgsman W (2002) The Mediterranean: Mare Nostrum of Earth sciences. Earth Planet Sci Lett 205:1-12

Lavoie DM, Smith LD, Ruiz GM (1999) The potential for intracoastal transfer of non-indigenous species in the ballast water of ships. Estuar Coast Shelf Sci 48:551-564

Legendre P, Legendre L (2000) Numerical ecology, 2nd edn. Elsevier Science BV, Amsterdam

Magazzù G, Andreoli C (1971) Trasferimenti fitoplantonici attraverso lo stretto di Messina in relazione alle condizioni idrologiche. Bolletino di Pesca, di Piscicoltura e di Idrobiologia 26:125-191

Marbà N, Duarte CM (1997) Interannual changes in seagrass (Posidonia oceanica) growth and environmental change in the Spanish Mediterranean littoral. Limnol Oceanogr 42: $800-810$

Marty JC, Chiavérini J, Pizay MD, Avril B (2002) Seasonal and interannual dynamics of nutrients and phytoplankton pigments in the western Mediterranean Sea at the DYFAMED time-series station (1991-1999). Deep-Sea Res II 49:1965-1985

Mikaelyan AS, Zavyalova TA (1999) Vertical distribution of heterotrophic phytoplankton in the Black Sea during the summer period. Oceanol Russian Acad Sci 39:893-902

> Murphy JM, Sexton DMH, Barnett DN, Jones GS, Webb MJ, Collins M, Stainforth DA (2004) Quantification of modelling uncertainties in a large ensemble of climate change simulations. Nature 430:768-772

Nehring S (1998) Establishment of thermophilic species in the North Sea: biological indicators of climatic change? ICES J Mar Sci 55:818-823

Ochoa NL, Gómez OC (1997) Dinoflagelados del mar peruano como indicadores de masas de agua durante los años 1982 a 1985. Bol Inst Mar Perú 16:1-60

Okolodkov YB (1996) Net phytoplankton from the Barents Sea and Svalbard waters collected on the cruise of the R/V 'Geolog Fersman' in July-September 1992, with emphasis on the Ceratium species as biological indicators of the Atlantic waters. Bot J Russian Acad Sci 81:1-9

Parmesan C, Yohe G (2003) A globally coherent fingerprint of climate change impacts across natural systems. Nature 421:37-42

Parmesan C, Ryrholm N, Stefanescu C, Hill JK and others (1999) Poleward shifts in geographical ranges of butterfly species associated with regional warming. Nature 399: 579-583

Pavillard J (1934) Les Péridiniens et Diatomées pélagiques de la mer de Monaco pendant les années 1907 et 1908. Bull Inst Oceanogr Monaco 654:1-6

Pavillard J (1936) Les Péridiniens et Diatomées pélagiques de la mer de Monaco pendant les années 1909, 1910 et 1911. Bull Inst Oceanogr Monaco 712:1-6

Pavillard J (1937a) Les Péridiniens et Diatomées pélagiques de la mer de Monaco pendant les années 1912, 1913 et 1914. Bull Inst Oceanogr Monaco 727:1-8

Pavillard J (1937b) Les Péridiniens et Diatomées pélagiques de la mer de Monaco de 1907 à 1914. Observations générales et conclusions. Bull Inst Oceanogr Monaco 738: $1-56$

> Perry AL, Low PJ, Ellis JR, Reynolds JD (2005) Climate change and distribution shifts in marine fishes. Science 308:1912-1915

Raine R, White M, Dodge JD (2002) The summer distribution of net plankton Dinoflagellates and their relation to water movements in the NE Atlantic Ocean, west of Ireland. J Plankton Res 24:1131-1147

Ribera d'Alcalà M, Conversano F, Corato F, Licandro P and others (2004) Seasonal patterns in plankton communities in a pluriannual time series at a coastal Mediterranean site (Gulf of Naples): an attempt to discern recurrences and trends. Sci Mar 68:65-83

Rohling EG, Bryden HL (1992) Man-induced salinity and temperature increases in western Mediterranean deep water. J Geophys Res 97:11191-11198

Sanchez G, Calienes R, Zuta S (2000) The 1997-98 El Niño and its effects on the coastal marine ecosystem off Peru. Rep CCOFI 41:62-86

$>$ Smalley GW, Coats DW, Adam EJ (1999) A new method using microspheres to determine grazing on ciliates by the mixotrophic dinoflagellate Ceratium furca. Aquat Microb Ecol 17:167-179 
Sournia A (1967) Le genre Ceratium (Péridinien planctonique) dans le canal du Mozambique. Contribution à une révision mondiale. Vie Milieu Ser A Biol Mar 18:375-500

Sournia A (1986) Classe des Dinophycées. In: Sournia A (ed) Atlas du phytoplancton marin. Centre National de la Recherche Scientifique, Paris, p 26-98

Steidinger KA, Tangen K (1997) Dinoflagellates. In: Tomas CR (ed) Identifying marine phytoplankton. Academic Press, New York, p 387-584

Trégouboff G, Rose M (1957a) Manuel de planctonologie méditerranéenne, Tome I. Centre National de la Recherche Scientifique, Paris

Editorial responsibility: Katherine Richardson,

Copenhagen, Denmark
Trégouboff G, Rose M (1957b) Manuel de planctonologie méditerranéenne, Tome II. Centre National de la Recherche Scientifique, Paris

Tunin-Ley A, Labat JP, Gasparini S, Mousseau L, Lemée R (2007) Annual cycle and diversity of species and infraspecific taxa of Ceratium Schrank (Dinophyceae) in the Ligurian Sea, NW Mediterranean. J Phycol 43:1149-1163

van Herk CM, Aptroot A, van Dobben HF (2002) Long-term monitoring in the Netherlands suggests that lichens respond to global warming. Lichenologist 34:141-154

Walther GR (2000) Climatic forcing on the dispersal of exotic species. Phytocoenologia 30:409-430

Submitted: January 21, 2008; Accepted: September 5, 2008 Proofs received from author(s): January 13, 2009 